\title{
New biogeographical distribution of fish Glyptothorax conirostris, G. telchitta and G. cavia (Siluriformes: Sisoridae) in northern plain tributaries of the Ganges basin, India
}

\author{
Uttam Kumar Sarkar, Gazala Eran Khan, Sanjay Christopher Rebello, Vineet Kumar Dubey, Praveen Agnihotri, \\ Ajay Kumar Pathak, Amar Pal \& Sri Prakash Singh \\ National Bureau of Fish Genetic Resources, Canal Ring Road, Dilkusha, Lucknow- 226002, India. Phone: 91 (India)-522-2441735; Fax: 91 (India) - \\ 522-2442403; uksarkar1@nbfgr.res.in
}

Received 27-V-2013 • Corrected 6-VIII-2013 • Accepted 12-VIII-2013

\begin{abstract}
Sisorid catfish of the genus Glyptothorax are widely distributed, with as many as 40 nominal species reported from India, where they typically inhabit fast-flowing hill streams and faster flowing stretches of larger rivers and streams. We recorded new biogeographical distribution of three species of Glyptothorax from the tributaries of northern plains in the Ganges basin. The specimens were collected during experimental fishing for biodiversity studies using cast nets (2010-2012). While $G$. conirostris were collected from the Ganges canal, G. cavia and G. telchitta were captured from the river Gomti. Previous descriptions were based on preserved specimens; we present diagnostic features and an illustrated redescription based on fresh specimens.
\end{abstract}

KEY WORDS: new distribution, Glyptothorax conirostris, G. telchitta, G. cavia, tributary, Ganges basin, India.

\section{RESUMEN}

Los peces bagre del género Glyptothorax se distribuyen ampliamente, con nada menos que 40 especies nominales reportadas en India, donde normalmente habitan en arroyos de montaña con corrientes rápidas y tramos que fluyen más rápido en ríos y arroyos mas grandes. Registramos una nueva distribución biogeográfica de tres especies de Glyptothorax de las afluentes de las llanuras del norte de la cuenca del Ganges. Los especímenes se recolectaron durante la pesca experimental para estudios de biodiversidad con atarraya (2010-2012). Mientras que $G$. conirostris se capturó en el canal del río Ganges, G. cavia y $G$. telchitta fueron capturados en el río Gomti. Descripciones anteriores son basadas en especímenes preservados, presentamos características diagnósticas y redescripción ilustrada basada en especímenes frescos.

PALABRAS CLAVE: nueva distribución, Glyptothorax conirostris, G. telchitta, G. cavia, cuenca Ganges, India.
Sisorid catfish of the genus Glyptothorax are widely distributed and have nearly 40 nominal species reported from India (Jayaram, 2010; Talwar \& Jhingaran, 1991; Vishwanath \& Linthoingambi, 2007). They typically inhabit foothill rivers and fast flowing mountain streams and are benthic in habitat and maintain themselves attached to rocks, boulders, stones at the bottom of the water bodies where they live by means of a thoracic adhesive apparatus (Jayaram, 2010). This feature formed by a series of roughly parallel integumentary ridges and grooves, the ridges having dense covering of unculi. It is either thoracic or abdominal in location. They are distinguishable by a distinct thoracic adhesive apparatus (de Pinna, 1996). The genus Glyptothorax has received attention by many authors and some of the important contributions in India are Hora (1923), Menon (1974) and Vishwanath and Linthoingambi (2007). Li (1986) studied the systematic, distribution and evolution of genus. So far distribution is concerned the species is widely distributed in south Asia from Tigris- Euphrates basin eastward to Vietnam and eastern China while in the Indian region it is distributed in India, Bangladesh, Mayanmar and Pakistan (Jayaram, 2010).

Karmakar (2000) reported the distribution of 16 Glyptothorax species in the Himalayan drainage system (Eastern Himalaya, Northeastern Himalaya, Central Himalaya and Northwestern Himalaya). However, in the present study, we collected Glyptothorax conirostris, G. telchitta and G. cavia while conducting Germplasm exploration in the Ganges basin of Uttar Pradesh plains, 
India which is a new distribution record for all these species. In earlier studies G.conirostris, was described by Steindachner (1867) from Shimla, Himachal Pradesh Northwestern India. G. telchitta was described from Hooghly river, West Bengal (Hamilton, 1822; Jayaram 2010), while G. cavia was reported from rivers of Northern Bengal (Hamilton 1822) as per Jayaram (2010).

In a recent publication, Jayaram (2010) distinguished the genus from other members of the subfamily by the presence of greatly depressed head, thick and pappilated lips and ventral surface of thorax with an adhesive apparatus with or without a central pit. de Pinna (1996) diagnosed the genus by the following combination of characters, thorasic adhesive apparatus comprising an elliptical field of folded longitudinal pleats of skin, a detached distal portion of premaxilla, and long and thin lateral arms of the vomer that extend under the entire length of articular process of lateral ethmoid. As there is no previous record of G. telchitta, G. cavia and G. conirostris from the studied tributaries of Northern plains in Uttar Pradesh, our present report may be considered as the first evidence of a broader distributional range of Glyptothorax genus, indicating that the species may be more widely distributed than previously acknowledged.

\section{MATERIALS \& METHODS}

\section{Study area}

The Ganga is a major river of the Indian subcontinent rising in the Himalaya mountain and flowing about 2 $510 \mathrm{~km}$ generally eastward through a vast plain to the Bay of Bengal. The river flows southwest through the Indian state of Uttar Pradesh, Bihar and West Bengal. We collected $G$. conirostris from a canal connected with river Ganges in the northern plains $\left(12^{\circ} 49.400^{\prime} \mathrm{N}, 076^{\circ} 03.85^{\prime} \mathrm{E}\right)$. River Gomti is a major tributary of the Ganga River basin in Northern India. It originates from a natural reservoir in the forested area near Pilibhit town in Uttar Pradesh, about $50 \mathrm{~km}$ south of the Himalayan foothills. The river flowing through the central and eastern part of Uttar Pradesh traverses a total distance of about $730 \mathrm{~km}$ before finally merging in the Ganga River near Varanasi. We collected two individuals of $G$. cavia and one individual of $G$. telchitta from river Gomti at Pilibheet district. The specimen was collected using a castnet during November 2012 (Fig. 1). Digital photographs of the specimen were taken which was then fixed in $10 \%$ formaldehyde for further studies. A total of 13 morphometric and meristic characters was taken with a Mutiyoto digital caliper to the nearest $0.01 \mathrm{~mm}$. The specimen was subsequently identified following the taxonomic keys by Talwar and Jhingaran (1991) and Jayaram (2010).

\section{RESULTS}

\section{Description}

Morphometric and meristic details of $G$. conirostris, $G$. cavia and G. telchitta are presented in Table 1. Maximum total length (TL) reported as per Fish base is $14 \mathrm{~cm}$ for $G$. conirostris, $10 \mathrm{~cm}$ for $G$. telchitta and $28 \mathrm{~cm}$ for $G$. cavia. In the present study, average total length of $G$. conirostris was $127,4 \mathrm{~mm}$ with body depth $23,1 \mathrm{~mm}$. Body was elongated and strongly compressed. Head was broad and its length measured $2.8 \mathrm{~mm}$. Eyes were minute covered by skin, in middle of head. Dorsal fin was long inserted in posterior half of the body. Predorsal length was measured 45,8 which was shorter than post dorsal length. Rayed dorsal fin higher than body depth. Body depth $22,2 \%$ SL. Similarly total length of G. cavia was 79,2 and $79,5 \mathrm{~mm}$ respectively. Its body was also elongated, thin and strongly compressed. Measurement of head length was $1,8-1,6 \mathrm{~mm}$. Eyes were minute, thin and surrounded by skin in middle of the head. Least height of caudal peduncle $47 \%$ in its length. Least height of caudal peduncle less than $35 \%$ in its length. In G. telchitta total length recorded was $57,6 \mathrm{~mm}$ and $45,3 \mathrm{~mm}$ in standard length. Thorasic adhesive apparatus with narrow folds of skin and incompleted posteriorly. Nostrils separated from the snout by a distance equal to eye diameter. Caudal peduncle height $26,3-33.3 \%$ in its length and it was greater than $35 \%$ in its length. Due to its smooth and truncated body texture the species often become twisted and easily deformed even in best prepared samples.

\section{Habitat}

Water temperature show the collection site as 23,8 to $24,5^{\circ} \mathrm{C}$. Pools with lateral and scour riffles were major habitat characteristics, with substrate such as cobbles, and gravels, and a riparian cover of shrubs and small trees predominating in the collection area. Among other fish species in the river Ganges and Gomti Puntius sophore, P. sarana, Rasbora daniconius, Labeo rohita, Rita rita, Notopterus notopterus and Salmostoma bacaila were dominated. 

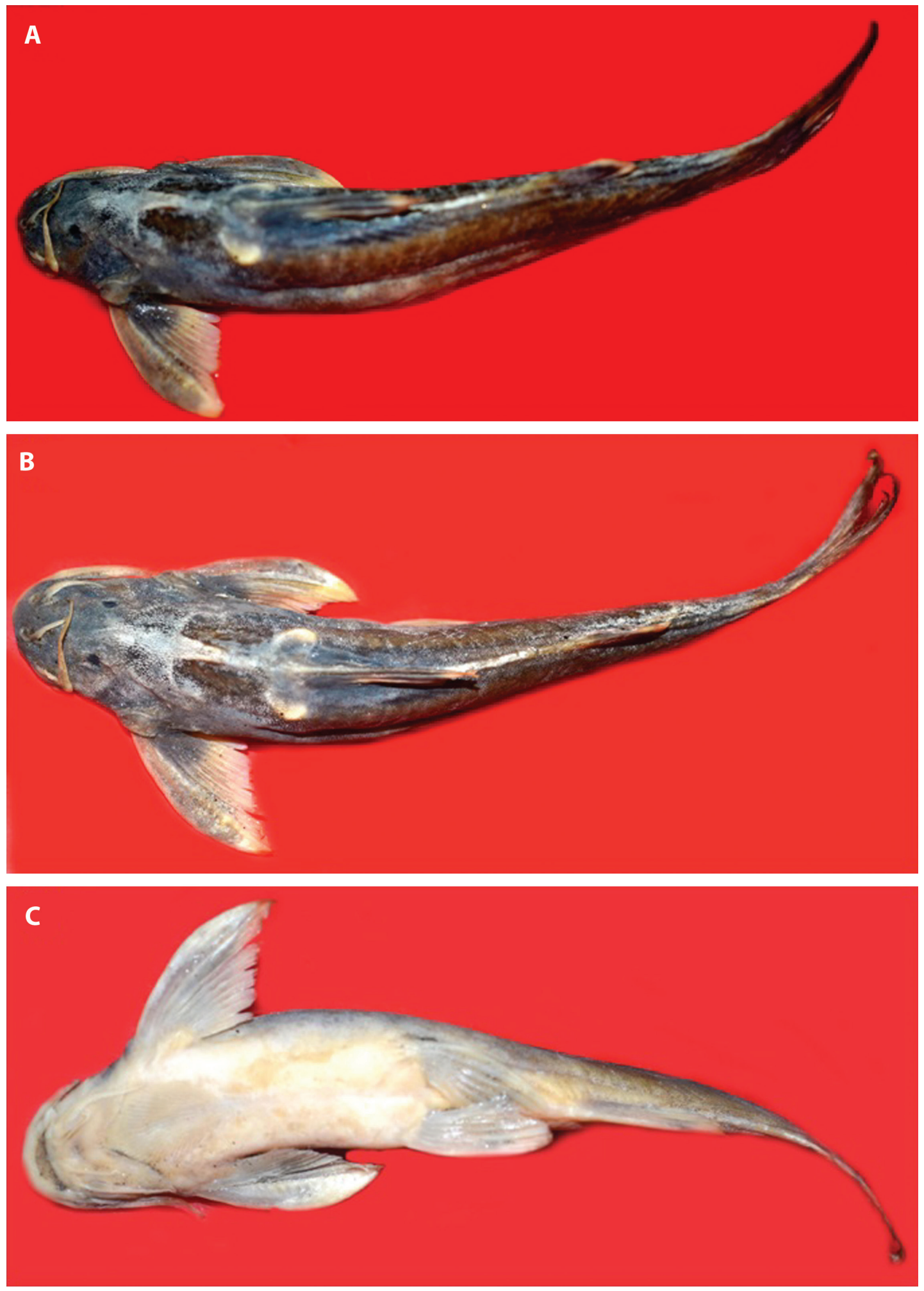

Fig. 1. Glyptothorax conirostris (a) lateral view (b) dorsal view (c) ventral view. 
TABLE 1

Morphometric details of three Glyptothorax species collected from river Ganges basin, India.

\begin{tabular}{|c|c|c|c|c|c|}
\hline \multirow[t]{2}{*}{ S.N. } & \multirow[t]{2}{*}{ Morphometric variables(mm) } & \multirow[t]{2}{*}{ G. conirostris } & \multicolumn{2}{|c|}{ G. cavia } & \multirow[t]{2}{*}{ G. telchitta } \\
\hline & & & Sample 1 & Sample 2 & \\
\hline & Total length & 127,4 & 79,2 & 79,5 & 57,6 \\
\hline & Fork length & 114,8 & 70 & 71 & 50,5 \\
\hline & Standard length & 109,8 & 61,5 & 60 & 45,3 \\
\hline & Body depth & 23,1 & 67,8 & 9,5 & 9,7 \\
\hline & Total body weight(g ) & 16,4 & 1,8 & 1,5 & 1,6 \\
\hline \multicolumn{6}{|c|}{ Relative characters } \\
\hline & Standard length/Body depth & 4,7 & 4,6 & 4,5 & 4,7 \\
\hline & Standard length/Head length & 3,3 & 3,5 & 3,4 & 3 \\
\hline & Head length/Eye diameter & 4 & 4,5 & 4 & 4 \\
\hline & Interorbital width/Eye diameter & 1,2 & 1,5 & 1,8 & 1,1 \\
\hline & Head length/Head width & 1,9 & 1,8 & 1,6 & 1,8 \\
\hline & Head length/ Mouth width & 1,8 & 1,7 & 1,5 & 1,7 \\
\hline \multicolumn{6}{|c|}{ Fin formula } \\
\hline & $\mathrm{D} / \mathrm{P} / \mathrm{V} / \mathrm{A} / \mathrm{C}$ & $7,19,6 / 6,4 / 18$ & $7,9,6,10,24$ & $7,9,6,10,24$ & $7,10,6,10,24$ \\
\hline & Predorsal length/postdorsal length & 45,$8 ; 55,8$ & 25,$1 ; 54,1$ & 24,$5 ; 56,1$ & 11,$5 ; 32,6$ \\
\hline
\end{tabular}
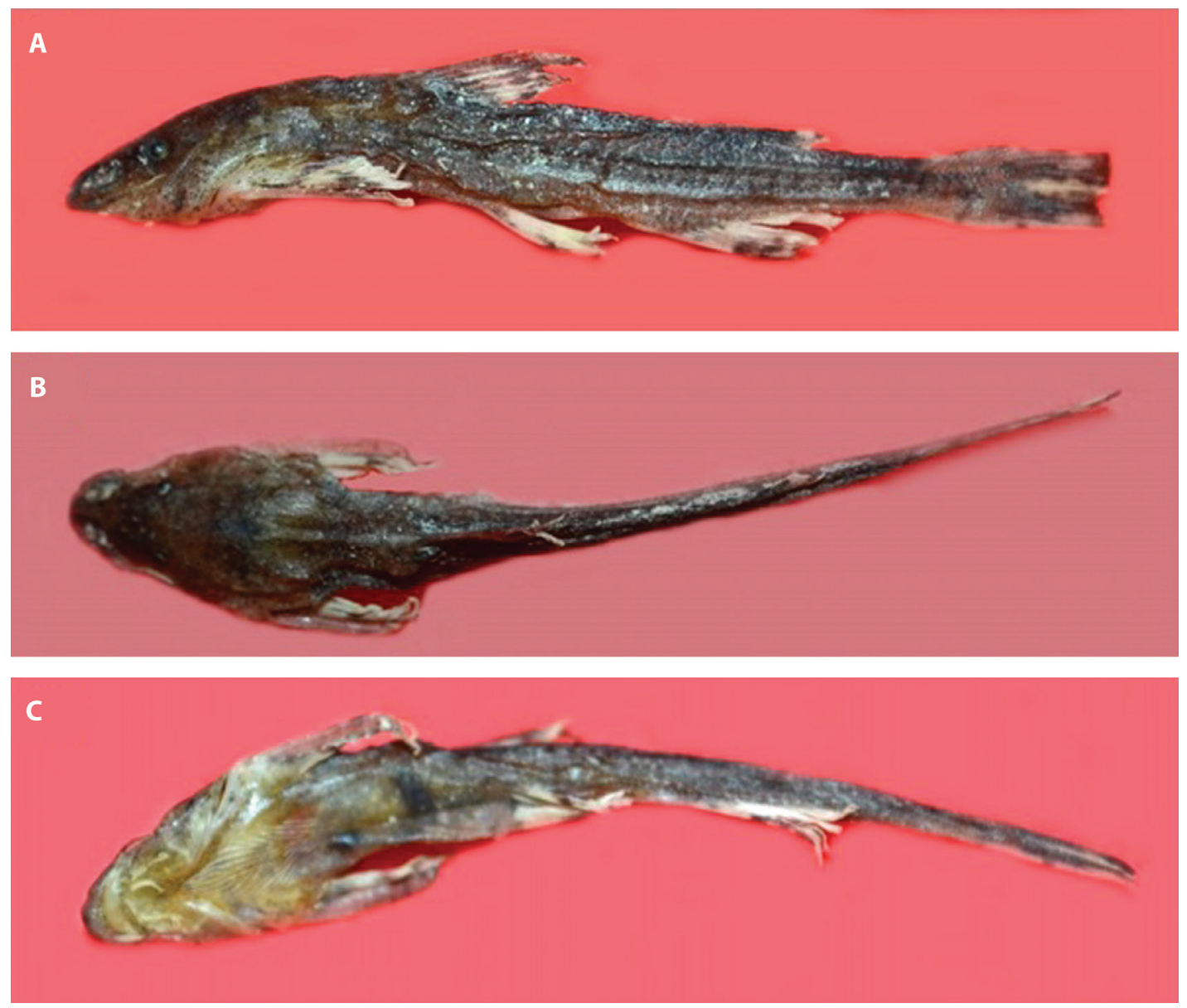

Fig. 2. Glyptothorax telchitta (a) lateral view (b) dorsal view (c) ventral view. 

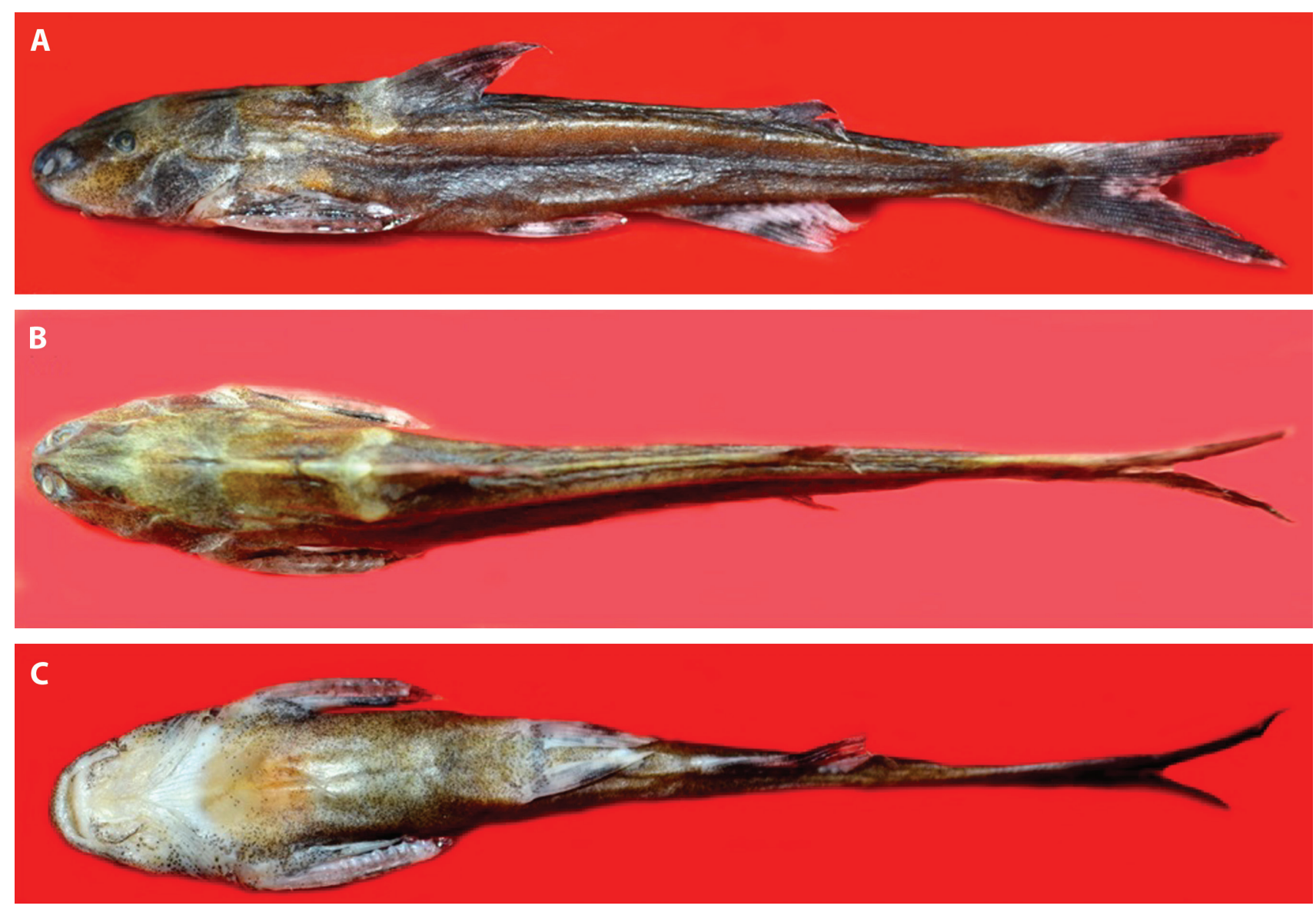

Fig. 3. Glyptothorax cavia (a) lateral view (b) dorsal view (c) ventral view.

\section{DISCUSSION}

In India, first description of G. conirostris was proposed by Steindachner (1867) from Northwestern India and subsequently from Garhwal Himalaya, Mahananda river, North Bengal ,headwaters of Poonchvally Shimla, and Tripura, respectively(Jayaram, 2010). First published record of G. cavia was from Northern Bengal and later reported from Assam, Terai region of North Bengal and Bihar, Meghalaya, Manipur, Hooglyriver at Kalna, West Bengal, Uttaranchal, Jammu and Kashmir. G. telchitta was recorded from Bihar, Garhwal in Western Himalaya, North Bengal. In Uttar Pradesh the species was reported from Vindhya region and river Rohini, Gorakhpur as cited in Jayaram (2010) and Srivastava (1988).Although the species G. conirostris, and G. telchitta has been reported earlier (Hora \& Menon, 1949; Menon, 1974; Jayaram, 2010) from the state of Uttar Pradesh, however, they were not reported from the tributaries explored under this study. Vishwanath, Lakra and Sarkar (2007) described G. chindwinica much similar to G. cavia in general appearance but can be easily distinguished in the nature of tooth band, length of thoracic adhesive apparatus, head size, nature of skin and type of band on caudal fin. Hora and Menon (1949) treated G. burmanicus a synonym of G. cavia.

The genus Glyptothorax is very important from a taxonomic point of view as several new species have been described from northeastern India in the past few years (Vishwanath \& Linthoingambi, 2007; Rameshori \& Vishwanath, 2012). Pandey, Dubey, Kumar, Sarkar and Lakra (2011) described new distribution record of G. brevipinnis from a tropical river Ken, Central India. Recently, 9 species of Glyptothorax have been described from North Estern Region of India (Viswanath et al., 2007). Dubey (2007) reported seven species (including G. telchitta) from Central India. In another study, Badola (2008) reported 8 species of Glyptothorax from the drainages of Central Himalayas. An updated list of 40 species of this genus and their distribution in Indian waters has been presented in Table 2 . The present distribution records of $G$. conirostris, G. telchitta and G. caviain the 
TABLE 2

Distribution record of the genus Glyptothorax in India.

\begin{tabular}{|c|c|c|c|}
\hline Species & Distribution & $\begin{array}{l}\text { Occurrence } \\
\text { locations }\end{array}$ & References \\
\hline Glyptothorax alaknandi & $\begin{array}{l}\text { Alaknanda river, Shrinagar, district Pauri Garhwal } \\
\text { (Uttarakhand) }\end{array}$ & 1 & Tilak, 1969 \\
\hline Glyptothorax anamalaiensis & Streams in Anamalai hills, Western ghats, Tamilnadu & 1 & Silas, 1952 \\
\hline Glyptothorax anandalei & $\begin{array}{l}\text { Nierolay stream, Bhawani river at the base of Nilgiri } \\
\text { hills, Nilgiri district, Tamilnadu }\end{array}$ & 8 & Hora, 1923 \\
\hline Glyptothorax botius & Hooghly river at Kalna, Westbengal \& Northeast India & 3 & Hamilton, 1822 \\
\hline Glyptothorax brevipinnis & Exact location unknown, River Tonse & 15,1 & $\begin{array}{l}\text { Hora, 1923; Pandey et al., } \\
2011\end{array}$ \\
\hline Glyptothorax cavia & $\begin{array}{l}\text { Northern Bengal, Eastern Himalayas, Assam, river } \\
\text { Gomti }\end{array}$ & 11,1 & $\begin{array}{l}\text { Hamilton, 1822; Present } \\
\text { study }\end{array}$ \\
\hline Glyptothorax chindwinica & Iril river, Urup, Manipur & 1 & $\begin{array}{c}\text { Vishwanath \& } \\
\text { Linthiongambi, } 2007\end{array}$ \\
\hline Glyptothorax conirostris & $\begin{array}{l}\text { Simla, Himachal Pradesh, Northwestern India, Western } \\
\text { Himalaya, Mahananda river, Siliguri, Ganges canal, } \\
\text { Roorkie }\end{array}$ & 11,1 & $\begin{array}{l}\text { Steindachner, 1867; } \\
\text { Menon 1974; present } \\
\text { study }\end{array}$ \\
\hline Glyptothorax coheni & Subarnarekha river, Chotanagpur, Jharkhand, India & Not known & Jayaram, 2010 \\
\hline Glyptothorax dakpathari & Jamuna river, Dehradun, Uttranchal, & 1 & \\
\hline Glyptothorax davissinghi & $\begin{array}{l}\text { Karim puzha, Maancheri, Nilambur reserve forest, } \\
\text { Kerala }\end{array}$ & 8 & $\begin{array}{l}\text { Manimekalan \& Das, } \\
1998\end{array}$ \\
\hline Glyptothorax garhwali & $\begin{array}{l}\text { Alaknanda, Bhilangana, Mandakini, Srinagar, Pauri } \\
\text { garhwal district, Sharda, Tarakpur, Nainital district, } \\
\text { Uttranchal, Nepal }\end{array}$ & 8 & Jayaram, 2010 \\
\hline Glyptothorax gracilis & $\begin{array}{l}\text { Yamuna river, below barrage, Dakpathar, district } \\
\text { Dehradun, Uttar Pradesh, Uttarakhand }\end{array}$ & 3 & Gunther, 1864 \\
\hline Glyptothorax granulus & Iril river, Phungdhar, Ukhurul district, Manipur & 1 & $\begin{array}{l}\text { Vishwanath \& } \\
\text { Linthiogambi, } 2007\end{array}$ \\
\hline Glyptothorax housei & $\begin{array}{l}\text { Mountain stream rapids, Anamalai hills, } 4 \text { miles east of } \\
\text { valparai poolachi district southern India }\end{array}$ & 2 & Herre, 1942 \\
\hline Glyptothorax indicus & $\begin{array}{l}\text { Sone river, Bihar, Moga, East Punjab, streams of Terai, } \\
\text { Eastern Himalaya, Kosi, Rihand river, U.P., India, Nepal }\end{array}$ & 6 & Jayaram, 2010 \\
\hline Glyptothorax kasmirensis & Kashmir valley & 8 & Hora, 1923 \\
\hline Glyptothorax kudremukhensis & $\begin{array}{l}\text { Streams in Thunga river headwaters, Maduba, } \\
\text { Kukdremukh national park, Karnataka, Western ghats }\end{array}$ & 3 & Gopi, 2007 \\
\hline Glyptothorax lonah & Deccan, Madhya Pradesh & 5 & Sykes, 1839 \\
\hline Glyptothorax madraspatanum & $\begin{array}{l}\text { Bowany (Bhawani) river Neilgherries (Nilgiris) Madras } \\
\text { state }\end{array}$ & 5 & Day, 1878 \\
\hline Glyptothorax manipurensis & $\begin{array}{l}\text { Barak river at Karong, Naga hills at Manipur state, } \\
\text { Assam }\end{array}$ & 3 & Menon, 1955 \\
\hline Glyptothorax nelsoni & Subarnarekha river, Chota Nagpur, Jharkhand & 2 & Jayaram, 2010 \\
\hline Glyptothorax ngapang & Chindwin basin in Manipur, India & 1 & $\begin{array}{l}\text { Vishwanath \& } \\
\text { Linthiogambi, } 2007\end{array}$ \\
\hline Glyptothorax pectinopterus & Ganges river drainages & 24 & McClelland, 1842 \\
\hline
\end{tabular}


TABLE 2 (Continued)

Distribution record of the genus Glyptothorax in India.

\begin{tabular}{|c|c|c|c|c|}
\hline S.N. & Species & Distribution & $\begin{array}{l}\text { Occurrence } \\
\text { locations }\end{array}$ & References \\
\hline & Glyptothorax poonaensis & $\begin{array}{l}\text { Mula mutha river at Poona, Maharashatra, Bombay, } \\
\text { Mumbai state }\end{array}$ & 1 & Hora, 1938 \\
\hline & Glyptothorax stolickae & Simla, Himachal pradesh & 1 & Steindachner, 1867 \\
\hline & Glyptothorax striatus & Meghana \& Brahamputra drainages India & 3 & McClelland, 1842 \\
\hline & Glyptothorax telchitta & $\begin{array}{l}\text { Hoogly river at Kalna, North Bengal, River Rohini } \\
\text { Gorakhpur,Vindhya region of Uttar Pradesh, North } \\
\text { Bihar, Madhya Pradesh, river Gomti }\end{array}$ & 9,1 & $\begin{array}{l}\text { Hamilton, 1822; } \\
\text { Srivastava, 1988; Menon, } \\
\text { 1974; Present study }\end{array}$ \\
\hline & Glyptothorax trilineatus & $\begin{array}{l}\text { Chindwin basin, Manipur, Alaknanda river, Garhwal, } \\
\text { Himalaya }\end{array}$ & 11 & Blyth, 1860 \\
\hline & Glyptothorax trewavaseae & Yenna valley, Satara district, Maharashtra & 3 & Hora, 1938 \\
\hline & Glyptothorax ventrolineatus & Iril river, Ukhruk district, Manipur & 1 & $\begin{array}{l}\text { Vishwanath \& } \\
\text { Linthiongambi, } 2007\end{array}$ \\
\hline & Glyptothorax naziri & Punjab & 1 & Jayaram, 2010 \\
\hline & Glyptothorax ngapang & Manipur, Barak river & 2 & $\begin{array}{l}\text { Vishwanath \& } \\
\text { Linthiongambi, } 2007\end{array}$ \\
\hline & Glyptothorax nelsoni & Subarnarekha river, Chota Nagpur, Jharkhand, India & 2 & Jayaram, 2010 \\
\hline & Glyptothorax pectinoperus & $\begin{array}{l}\text { Nainital, Punjab, Song river Dehradoon, Sutlej, } \\
\text { Yamuna, Uttaranchal }\end{array}$ & 7 & \\
\hline & Glyptothorax platypogonides & Manipur & 1 & \\
\hline & Glyptothorax saisii & $\begin{array}{l}\text { Subarnarekha river, Paresnath hills, Garhwal, } \\
\text { Saharanpur, Uttar Pradesh }\end{array}$ & 6 & \\
\hline & Glyptothorax sinensis & Barak river, Kasong, Assam, Manipur India & 5 & \\
\hline & Glyptothorax striatus & Cherapunji, Khasi hills, Someswar river, Barapani lake & 6 & \\
\hline & Glyptothorax stoliczkae & Headwaters of Jamuna, Shimala, Western Himalaya & 2 & \\
\hline
\end{tabular}

explored tributaries of Ganges basin add a new location to the known range of the species in the northern plains of Uttar Pradesh. We believe the population of three Glyptothorax species descried here to be in a precarious state due to climatic variations and therefore more studies on biogeography of species in Northern India needs to be encouraged. There is also a need to characterize the population using morphological and molecular tools. As our report is based on low sample size additional catches of the specimens are needed to confirm whether there is an established population of the species in this locality.

\section{ACKNOWLEDGEMENTS}

The authors would like to thank the Director, NBFGR, Lucknow, for providing the necessary facilities and suggestions. The authors are also indebted to Uttar Pradesh Biodiversity Board, Lucknow, Government of Uttar
Pradesh, India for providing financial assistance to carry out the biodiversity and exploration study.

\section{REFERENCES}

Badola, S. P. (2008). Ichthyology of the Central Himalaya. Bhandari Bagh, Srinagar (Garhwal), Uttarakhand: Trans Media publication, Media house.

Blyth, E. (1860). Report on some fishes received chiefly from Sittand river and its tributary streams. Journal of the Asiatic Society Calcutta, 29,138-174.

Day, F. (1878). The fishes of India: being a natural history of the fishes known to inhabit the seas and fresh waters of India. London, England: Burma and Ceylon.

de Pinna, M. C. C. (1996.) A phylogenetic analysis of the Asian catfish families Sisoridae, Akysidae and Amblyceplitidae, with a hypothesis on the relationship of neotropical 
Aspredinidae (Teleostei, Ostariophysi). Fieldiana: Zoology (New Series), 84, 1-83.

Dubey, G. P. (2007). A review of Fish Fauna of Madhya Pradesh (1956-2001) with their present status. In Lakra, W.S., Sarkar U.K. (Ed.) Freshwater fish diversity of Central India (pp 19-32). Dilkusha, Lucknow: National Bureau of Fish Genetic Resources.

Günther, A. (1864). Catalogue of the fishes in the British Museum. Volume Five. London: Trustees of the British Museum.

Gopi, K.C. (2007). Glyptothorax kudremukhiensis. Fauna of Kudremukh National Park (Karnataka). Kolkata: Zoological Survey of India.

Hamilton-Buchanan, F. (1822). An account of the fishes of found in the Ganges and its branches. Edinburg, London: Archibald Constable Company.

Herre, A. W. C. T. (1942). Glyptothorax housei, a new sisorid catfish from south India. Stanford Ichthyological Bulletin, 2(4), 117-119.

Hora, S. L. (1923). Notes on fishes in Indian museum. On the composite genus Glyptosternun McClleland. Records of Indian museum, 25(1), 29.

Hora, S. L., \& Menon, M. A. S. (1949). Fish fauna of the Rihand river and its zoogeographical significance. Journal of Zoological Society of India, 1(1), 1-6.

Hora, S. L. (1938). Notes on fishes in the Indian Museum. XXXVIII. On the systematic position of Bagruslonah Sykes, with descriptions of and remarks on other Glyptosternoid fishes from the Deccan. Records of the Indian Museum, 40(4), 363-375.

Jayaram, K. C. (2010). The freshwater fishes of the Indian region. Delhi, India: Narendra Publishing House.

Karmakar, A. K., (2000). Fish communities and their distribution in Himalayan drainage system. Records of the Zoological Survey of India, 98, 25-37.

Li, S. (1986). Systematics, distribution and evolution of Glyptothorax (Siluriformes: Siluridae) Indo pacific fish biology, proceeding of the second international conference on indo pacific fishes. Tokyo, Japan: Ichthyological Society of Japan.

Manimekalan, A., \& Das, H. S. (1998). Glyptothorax davissinghi (Pisces: Sisoridae) a new cat fish from Nilambur in the Nilgiri Biosphere Reserve, South India. Journal of the Bombay Natural History Society, 95(1), 87-91.
Mc Clelland, J. (1842). On the fresh-water fishes collected by William Griffith, Esq., F. L. S. Madras Medical Service, during his travels under the orders of the Supreme Government of India, from 1835 to 1842. Calcutta Journal of Natural History, 2(8), 560-569.

Menon, A. G. K. (1955). Further observations on the fish fauna of the Manipur state. Records of Indian Museum, 52, 21-26.

Menon, A. G. K. (1974). A checklist of fishes of the Himalayan and the Indo-gangetic plains. Special publication no 1. CIFRI, Barrackpore: Inland Fisheries Society of India.

Pandey, A., Dubey, V. K., Kumar, R. S., Sarkar, U. K., \& Lakra, W. S. (2011). New record of Glyptothorax brevipinnis (Hora 1923) (Pisces, Siluriformes, Sisoridae) in the river Ken, Central India. Journal of Applied Ichthyology, 27(4), 1112-1115.

Rameshori, Y., \& Vishwanath, W. (2012). Glyptothorax verrucosus, a new sisorid catfish species from the Koladyne basin, Mizoram, India (Teleostei: Sisoridae) (2012). Ichthyological Exploration in Freshwaters, 23(2), 147-154.

Silas, E.G. (1952). Notes on fishes of the genus Glyptothorax Blyth from Peninsular India, with description of a new species. Journal of the Bombay Natural History Society, 50(2), 367-370.

Srivastava, G. J. (1988). Fishes of U. P and Bihar. Varanasi, India: Vishwavidyalaya Prakashan.

Steindachner, F. (1867). Ichthyologische Notizen (IV). Sitz. MathNatur. Kla.Kais.Aka.Wissen, 55, 517-534.

Sykes, W. H. (1839). On the fishes of the Deccan. Proceedings of the General Meetings for Scientific Business of the Zoological Society of London, 6, 157-165.

Talwar, P. K., \& Jhingaran, A. G. (1991). Inland fishes of India and adjacent countries. New Delhi: Oxford and IBH publishing co.

Tilak, R. (1969). Descriptions of two new sisorids and a hybrid carp from Pauri, Garhwal (Kamaon Hills) Uttar Pradesh. Journal of the Inland Fisheries Society of India, 1, 37-48.

Vishwanath, W., \& Linthoingambi, I. (2007). Fishes of the genus Glyptothorax Blyth (Teleostei: Sisoridae) from Manipur India, with description of three new species. Zoos print journal, 22(3), 2617-2626.

Vishwanath, W., Lakra, W. S., \& Sarkar, U. K. (2007). Fishes of Northeast India. Lucknow, India: National Bureau of Fish Genetic Resources. 